\title{
Agosto e as Eleições
}

\section{Colega,}

Neste mês de agosto, ocorrerão eleições em importantes órgãos associativos da Medicina Brasileira. As Associações Médicas, Brasileira e Estaduais, e o Conselho Federal de Medicina estarão escolhendo seus dirigentes para as próximas gestões.

Estes são momentos únicos e muito importantes para todos os médicos brasileiros, em especial para nós tocoginecologistas. Da escolha desses dirigentes dependerá nosso futuro como classe, sobretudo na defesa de nossos interesses, na divulgação da ciência, na criação e no apoio às campanhas para melhoria da qualidade da assistência médica prestada à mulher brasileira.

A FEBRASGO espera que todos votem e que a escolha dos candidatos seja realizada após análise profunda e séria das suas propostas. Cumpre ressaltar que é através do voto que preparamos o nosso futuro.

Não se omita. Vote com consciência!
A Diretoria 